\title{
Вплив гіпоандрогенемії на складові метаболічного синдрому в підлітків із затримкою статевого розвитку
}

\section{Н.В. Шляхова ${ }^{1,2}$, C.I. Турчина ${ }^{1,2,3}$, Г.В. Косовцова ${ }^{1,2}$}

'ДУ «|нститут охорони здоров'я дітей та підлітків НАМН України», м. Харків

${ }^{2}$ Харківський національний університет ім. В.Н. Каразіна, МОН України

${ }^{3}$ Харківська медична академія післядипломної освіти, МОЗ України

Резюме. Мета — дослідити вплив гіпоандрогенемії (ГА) на формування компонентів метаболічного синдрому (МС) у хлопців із затримкою статевого розвитку. Матеріал і методи. Комплексне дослідження проведено у 55 хлопців 14-18 років із клінічними ознаками затримки статевого розвитку та лабораторно підтвердженим зниженим рівнем тестостерону ( $<12,0$ нмоль/л) (основна група). Групу порівняння становили 44 практично здорових однолітки із нормальним рівнем статевого дозрівання. Оцінювали статевий та фізичний розвитокхлопців. Визначали рівні загального тестостерону (ЗТ) та естрадіолу ( $\left.\mathrm{E}_{2}\right)$, сексстероїдзв'язуючого глобуліну (СЗГ), загального холестерину (ЗХС), тригліцеридів (ТГ), холестерину ліпопротеїдів високої щільності (ХС ЛПВЩ), рівень натще глюкози та імунореактивного інсуліну в сироватці крові. Розраховували співвідношення (T/E 2 ), індекс вільного андрогена (IBA); показники холестерину ліпопротеїдів низької щільності (ХС ЛПНЩ) та коефіцієнту атерогенності (KA), індекс інсулінорезистентності НОМА. Статистичний аналіз виконано в програмі SPSS17.00. Результати. У підлітків із ГА зниження рівня ЗТ поєднувалось із достовірними зменшеннями співвідношення T/E $\mathrm{E}_{2}(40,35 \pm 28,02$ ум.од., $\mathrm{p}<0,05)$ та IBA $(22,08 \pm 6,05$ ум. од., $\mathrm{p}<0,05)$ на тлі зниження рівня С Г $(28,11 \pm 3,64$ нмоль/л, p<0,05). За індивідуального аналізу у 23,6\% хворих із ГА діагностовано ознаки інсулінорезистентності (IP). Вста-

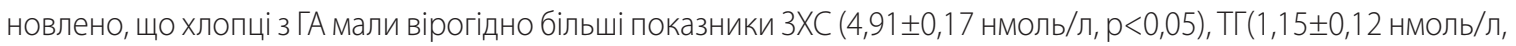
$\mathrm{p}<0,05)$ та ХС ЛПНЩ $(2,65 \pm 0,19$ нмоль/л, $\mathrm{p}<0,05)$ порівняно зі здоровими однолітками. Доведено наявність негативних зв'язків рівнів 3Т, СЗГ із вмістом 3ХС та позитивного зв'язку $\mathrm{E}_{2}$ із 3ХС, які не залежали від віку та індексу маси тіла (IMT). Висновки. Низькі рівні ЗТ у хлопців вже в підлітковому віці асоціюються з порушеннями ліпідного профілю, які можуть бути предиктором формування МС. Підлітки з ГА потребують динамічного спостереження та комплексного лікування, спрямованого на покращення репродуктивного потенціалу та попередження прогресування метаболічних порушень.

Ключові слова: хлопці, гіпоандрогенемія, метаболічний синдром.

* Адреса для листування (Correspondence): ДУ «Інститут охорони здоров'я дітей

і підлітків НАМН України», просп. Ювілейний, 52-А, м. Харків, 61153, Україна

E-mail: svetlanaturchina00@gmail.com

(ㄱ. Н.В. Шляхова, С.І. Турчина, Г.В. Косовчова 
Загальновідомо, що андрогенна недостатність призводить до порушень метаболічних процесів у чоловічому організмі, які є основою для виникнення та прогресування патологічних змін у системах внутрішніх органів [1-3]. Встановлено зв'язок андрогенодефіциту з вісцерально-абдомінальним ожирінням, цукровим діабетом 2-го типу, артеріальною гіпертензією, дисліпідеміями, МС у цілому, які є чинниками ризику розвитку серцево-судинних захворювань. Встановлено, що низький рівень тестостерону (Т) у крові в чоловіків середнього віку є предиктором ризику розвитку в літніх чоловіків захворювань, які є складовими МС, причому ризик розвитку абдомінального ожиріння в них зростає у 2,7 раза, цукрового діабету 2-го типу - у 2,1 раза, артеріальної гіпертензії - у 1,8 раза, гіперліпідемії - у 1,5 раза порівняно з чоловіками з нормальною концентрацією Т у крові чоловіків. Проте ці дані стосуються чоловіків середнього та похилого віку [4].

Отримано дані, що в чоловіків із низьким рівнем $\mathrm{T}$ відбувається підвищення рівнів ХС ЛПНЩ і ТГ на тлі зниження рівня ХС ЛПВЩ $[2,5]$. Своєю чергою, антиандрогенна терапія може призводити до підвищення рівнів ХС ЛПНЩ, ТГ, ліпопротеїну (а) (ЛП(а)) та зниження ХС ЛПВЩ. Проте замісна терапія Т не завжди дає очікуваний ефект щодо покращення ліпідного профілю, але терапія андрогенами у високих дозах може помітно знизити рівні ХС ЛПВЩ та ЛП(а) [2]. Також доведено, що замісна терапія Т зменшує прояви МС завдяки поліпшенню чутливості до інсуліну, збільшенню м’язової маси та зменшенню абдомінального ожиріння [6, 7].

Таким чином, наявні дані свідчать про наявність зв'язку між низьким рівнем андрогенів із компонентами МС у чоловіків. Так, у перехресних дослідженнях встановлені асоціації низьких концентрацій Т та СЗГ із вісцеральним ожирінням, IP, гіперінсулінемією та дисліпідемією [6, 9-11]. Однак зазначається, що не всі зв’язки можуть бути пояснені виключно надлишковим накопичуванням жиру в черевній порожнині $[10,11]$. Доведено, що низький рівень Т є предиктором прогресування абдомінального ожиріння та розвитку діабету [9, 12]. Дані щодо зв'язку дегідроепіандростерону з компонентами МС неоднозначні, але імовірно його низькі рівні корелюють із порушеннями толерантності до глюкози та чутливістю до інсуліну [11].

Слід зазначити, що більшість робіт, що вивчають питання ГА та їі взаємозв'язок із компонентами МС, стосуються чоловіків зрілого та похилого віку. Лише в поодиноких роботах розглядають питання низьких концентрацій андрогенів у молодих чоловіків (від 20 років). Роботи, які присвячені впливу ГА на метаболічний контроль у хлопців-підлітків, у доступній літературі відсутні. Зазначене вплинуло на обраний напрямок дослідження та його мету.

Мета - дослідити вплив ГА на формування компонентів МС у хлопців із затримкою статевого розвитку.

\section{Матеріал і методи}

Під спостереженням у відділенні ендокринології ДУ «ІОЗДП НАМН» перебувало 55 хлопців 14-18 років із клінічними ознаками затримки статевого розвитку (ЗСР) та лабораторно підтвердженим зниженим рівнем ЗТ (<12,0 нмоль/л) (основна група). Групу порівняння становили 44 практично здорових однолітки з нормальним рівнем статевого дозрівання. У всіх хлопців вивчали ступінь розвиненості вторинних статевих ознак за W.A. Marshal i J.M. Tanner [14], розраховували індекс маскулінізації (IM). Отримані результати співставлені з віковими нормативними показниками. ЗСР діагностували в разі уповільнення темпів статевого розвитку більш ніж на два роки [15]. Під час обстеження хлопців було виключено первинний або вторинний гіпогонадизм як причина дефіциту тестостерону [13]. Характер фізичного розвитку (ФР) визначали шляхом порівняння основних антропометричних показників (зросту і маси тіла (MT)) та IMT із віковими нормативами відповідно Протоколам надання медичної допомоги дітям за спеціальністю «Дитяча ендокринологія» [13].

Визначення рівня 3Т, естрадіолу ( $\left.\mathrm{E}_{2}\right)$, С $3 Г$ проводили методом ELISA $з$ використанням тест-систем «Гранум» ( $\mathrm{T}, \mathrm{E}_{2}$, Україна), «Бест Діагностик» (СЗГ, Україна), «DВС» (ДГА, Канада). В якості нормативних показників статевих стероїдів використовували вікові нормативи, розроблені в нашому інституті [16]. 
Для непрямої оцінки вільного Т розраховували IBA, який отримують як коефіцієнт 100*T/ СЗГ [17]. Також розраховували співвідношення $\mathrm{T} / \mathrm{E}_{2}$. Проводилося дослідження ліпідного спектра крові: ЗХС, ТГ, ХС ЛПВЩ у сироватці крові 3 використанням наборів фірми «CormayMulti» (Польща), із розрахунком XC ЛПНЩ та коефіцієнту атерогенності (КА). Рівень інсуліну натще досліджувався методом імуноферментного аналізу на фотометрі «Humareader» (Німеччина) за допомогою комерційних наборів фірми «Monobind» (США). Уніфікованим глюкозооксидазним методом за допомогою комерційних наборів фірми «Генезис» (Світловодськ) також визначався рівень глюкози крові натще. НОМА розраховувався за формулою $\left(\mathrm{G}_{0}\right.$ x $\left.\mathrm{Ins}_{0}\right) / 22,5$, де $\mathrm{G}_{0}-$ рівень глюкози плазми крові натще, ммоль/л; Ins $_{0}$ вміст імунореактивного інсуліну в сироватці крові натще, мкО/мл. Наявність IP діагностувалась за умови рівня НОМА, вищого за 3,5 ум. од.

Дослідження проведено відповідно до принципів Гельсінської декларації Всесвітньої медичної асоціації, Конвенції Ради Свропи про права людини та біомедицину, матеріали перевірені та схвалені комітетом із біоетики інституту. Батьки всіх пацієнтів надали письмову інформовану згоду на проведення комплексного обстеження та обробку його результатів.

Для статистичного аналізу використовували SPSS17.00. Отримані дані підпорядковувалися нормальному розподілу, були скореговані за віком та IMT (з метою виключення їх впливу на гормональні та біохімічні показники) і узагальнені по групах із використанням середнього (M) і стандартної помилки середнього (m). Аналіз змінних проводили за допомогою загальної лінійної моделі. Для оцінки зв'язку між статевими гормонами і показниками МС застосовували множинну лінійну регресію. Значення $\mathrm{p}<0,05$ вважали статистично значущим.

\section{Результати та обговорення}

Клінічне обстеження підлітків основної групи та групи порівняння не визначило вірогідних відмінностей за віком $(15,72 \pm 0,27$ та $16,03 \pm 0,14$ років відповідно, $\mathrm{p}<0,05)$ та IMT

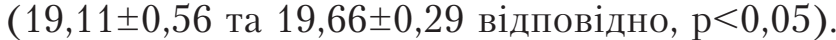
Між тим, під час індивідуального аналізу характеру ФР у 6 хворих (10,9\%) із ГА було встановлено надлишкову МТ або ожиріння, а 13 хлопців (23,6\%), навпаки, мали недостатню МТ. Серед практично здорових підлітків більшість мали нормальну МТ та гармонійний ФР, лише у 2 (4,5\%) спостерігалась надлишкова MT.

Незалежно від характеру ФР рівень артеріального тиску в обох групах не перевищував вікові нормативні показники.

Відповідно даним, наведеним в таблиці 1, хворі з ГА мали нормальні рівні $\mathrm{E}_{2}$, але вірогідно менші показники співвідношення $\mathrm{T} / \mathrm{E}_{2}$. Також у хлопців із ГА встановлено достовірне зниження вмісту СЗГ та зменшення IBA.

Незважаючи на те, що середні показники рівня глікемії натще, імунореактивного інсуліну та значень індексу НОМА у хлопців основної групи та групи порівняння вірогідно не відрізнялись, за індивідуального аналізу ознаки IP було діагностовано у 23,6\% підлітків із ГА, переважно за рахунок підвищення вмісту інсуліну. Збільшений рівень глюкози натще зареєстровано у 2-х підлітків.

Вивчення показників ліпідного профілю дозволило встановити, що хворі з ГА мали вірогідно більш високі рівні ЗХС, ТГ та ХC ЛПНЩ порівняно зі здоровими однолітками (таблиця 1). Слід зазначити, що індивідуальний аналіз показав, що в пацієнтів із ГА найчастіше порушення ліпідного профілю характеризувалися підвищеними рівнями 3ХC (54,6\%) та ХС ЛПНЩ (41,8\%). Високі рівні ТГ спостерігалися в $14,5 \%$, а зниження концентрації ХС ЛПВЩ зустрічалося лише в поодиноких випадках. У цілому, вміст ХC ЛПВЩ у цій групі був дещо вищим за групу порівняння $(\mathrm{p}=0,08)$. Звертає увагу, що зазначені порушення вуглеводного та ліпідного обміну спостерігалися в підлітків як із надлишковою, так і нормальною МТ.

3 метою вивчення взаємозв'язків між клінічними, гормональними та біохімічними показниками в обстежених із ГА було проведено регресійний аналіз, що дозволило визначити наявність негативних зв’язків рівнів 3Т, СЗГ із вмістом 3ХС та позитивного зв'язку $\mathrm{E}_{2}$ із $3 \mathrm{XC}$, які не залежали від віку та IMT (таблиця 2). ЗТ також був пов'язаний з концентрацією ХС 
Таблиця 1. Гормональні та біохімічні показники в хлопців із ГА (основна група) та практично здорових однолітків (група

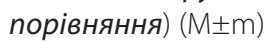

Table 1. Hormonal and biochemical characteristics in boys whith HA (main group) and practically healthy peers (comparison group) $(\mathrm{M} \pm \mathrm{m})$

\begin{tabular}{|c|c|c|c|}
\hline $\begin{array}{l}\text { Показники } \\
\text { Characteristics }\end{array}$ & $\begin{array}{l}\text { Основна } \\
\text { група } \\
\text { Main group } \\
(n=55)\end{array}$ & $\begin{array}{l}\text { Група } \\
\text { порівняння } \\
\text { Comparison } \\
\text { group } \\
(\mathrm{n}=44)\end{array}$ & $\mathrm{p}$ \\
\hline \multicolumn{4}{|l|}{$\begin{array}{l}\text { Гормональні показники } \\
\text { Hormonal characteristics }\end{array}$} \\
\hline $\begin{array}{l}\text { ЗТ, нмоль/л } \\
\text { Total testosterone, } \\
\mathrm{nmol} / \mathrm{L}\end{array}$ & $4,82 \pm 1,37$ & $24,38 \pm 2,27$ & $<0,05$ \\
\hline $\begin{array}{l}\mathrm{E}_{2^{\prime}} \text { нмоль/л } \\
\text { Total estradiol, } \mathrm{nmol} / \mathrm{L}\end{array}$ & $0,18 \pm 0,01$ & $0,17 \pm 0,03$ & $>0,05$ \\
\hline $\begin{array}{l}\text { ЗТ/E }{ }_{2^{\prime}} \text { ум.од. } \\
\text { TТ/E }{ }_{2^{\prime}} \text { c.u. }\end{array}$ & $40,35 \pm 4,02$ & $146,67 \pm 15,93$ & $<0,05$ \\
\hline $\begin{array}{l}\text { СЗГ, нмоль/л } \\
\mathrm{SHBG}, \mathrm{nmol} / \mathrm{L}\end{array}$ & $28,11 \pm 3,64$ & $51,18 \pm 5,73$ & $<0,05$ \\
\hline $\begin{array}{l}\text { IBA, ум.од. } \\
\text { FAI, с.и. }\end{array}$ & $16,08 \pm 2,05$ & $46,84 \pm 5,62$ & $<0,05$ \\
\hline $\begin{array}{l}\text { Інсулін, МО/л } \\
\text { Insulin, IU/L }\end{array}$ & $14,05+1,73$ & $12,36+1,91$ & $>0,05$ \\
\hline \multicolumn{4}{|c|}{$\begin{array}{l}\text { Біохімічні показники } \\
\text { Biochemical characteristics }\end{array}$} \\
\hline $\begin{array}{l}\text { Глюкоза, ммоль/л } \\
\text { Glucose, mmol/L }\end{array}$ & $4,47 \pm 0,08$ & $5,15 \pm 0,17$ & $>0,05$ \\
\hline $\begin{array}{l}\text { НОМА, ум.од. } \\
\text { HOMА, с.u. }\end{array}$ & $2,8+0,36$ & $2,6 \pm 0,24$ & $>0,05$ \\
\hline $\begin{array}{l}\text { ЗХС, ммоль/л } \\
\text { Total cholesterol, } \\
\mathrm{mmol} / \mathrm{L}\end{array}$ & $4,91 \pm 0,17$ & $3,52 \pm 0,34$ & $<0,05$ \\
\hline $\begin{array}{l}\text { TГ, ммоль/л } \\
\text { TG, mmol/L }\end{array}$ & $1,15 \pm 0,12$ & $0,58 \pm 0,37$ & $<0,05$ \\
\hline $\begin{array}{l}\text { XС ЛПНЩ, ммоль/л } \\
\mathrm{LDL}-\mathrm{C}, \mathrm{mmol} / \mathrm{L}\end{array}$ & $2,65 \pm 0,19$ & $1,76 \pm 0,29$ & $<0,05$ \\
\hline $\begin{array}{l}\text { XС лПВЩ, ммоль/л } \\
\mathrm{HDL}-\mathrm{C}, \mathrm{mmol} / \mathrm{L}\end{array}$ & $1,75 \pm 0,09$ & $1,43 \pm 0,06$ & $>0,05$ \\
\hline $\begin{array}{l}\text { КА, ум.од. } \\
\text { АC, с.и. }\end{array}$ & $2,04 \pm 0,10$ & $1,90 \pm 0,2$ & $>0,05$ \\
\hline
\end{tabular}

Abbreviations: HA, hypoandrogenia; HOMA, homoeostasis model assessment; TC, total cholesterol; TG, triglycerides; $H D L$, high-density lipoprotein; $L D L$, low-density lipoprotein; $S H B G$, sex hormonebinding globulin; FAl, free androgen index; $E_{2^{\prime}}$ total estradiol; TT, total testosterone; AC, atherogenic coefficient

ЛПВЩ. Вірогідних зв’язків статевих стероїдів із показниками вуглеводного обміну не визначено (дані не наведено).

Наявні в літературі дані щодо зв'язку ГА та МС неоднозначні та стосуються переважно дорослих та літніх чоловіків. Відповідно сучасним поглядам, низький рівень Т у чоловіків є незалежним предиктором МС [18-20] та має таблиця 2. Асоціації статевих гормонів, СЗГ із показниками ліпідного профілю

Table 2. Associations of sex hormones, SHBG with indicators of a lipid profile

\begin{tabular}{|c|c|c|c|c|c|c|}
\hline $\begin{array}{l}\text { Показник } \\
\text { Charac- } \\
\text { teristics }\end{array}$ & $\begin{array}{l}\text { Тесто- } \\
\text { стерон } \\
\text { Testo- } \\
\text { sterone }\end{array}$ & $p$ & $\begin{array}{l}\text { Естра- } \\
\text { діол } \\
\text { Estra- } \\
\text { diol }\end{array}$ & $p$ & $\begin{array}{l}\text { С } 3 Г \\
\text { SHBG }\end{array}$ & $p$ \\
\hline $\begin{array}{l}3 \times C \\
T C\end{array}$ & $-0,545$ & 0,001 & 0,381 & 0,008 & $-0,398$ & 0,007 \\
\hline $\begin{array}{l}+ \text { Bik } \\
+ \text { age }\end{array}$ & $-0,618$ & 0,001 & 0,337 & 0,020 & $-0,382$ & 0,009 \\
\hline $\begin{array}{l}+\mathrm{Bik}+\mathrm{IMT} \\
+ \text { age+BMI }\end{array}$ & $-0,597$ & 0,001 & 0,318 & 0,022 & $-0,317$ & 0,027 \\
\hline $\begin{array}{l}\text { ХС ЛПНЩ } \\
\text { LDL-C }\end{array}$ & $-0,416$ & 0,025 & 0,184 & 0,359 & $-0,226$ & 0,239 \\
\hline $\begin{array}{l}+ \text { Bik } \\
+ \text { age }\end{array}$ & $-0,454$ & 0,023 & 0,184 & 0,373 & $-0,243$ & 0,243 \\
\hline $\begin{array}{l}+\mathrm{Bik}+\mathrm{IMT} \\
+\mathrm{age}+\mathrm{BMI}\end{array}$ & $-0,209$ & 0,396 & 0,101 & 0,599 & $-0,181$ & 0,337 \\
\hline
\end{tabular}

Зворотний зв'язок $з$ його компонентами [1]. Між тим, коли в чоловіків похилого віку було взято до уваги рівні ліпідів, С-реактивного протеїду, IMT і IP, Т втратив своє провідне значення в прогнозуванні МС, що дозволяє розглядати вплив зазначених маркерів, як опосередкований на взаємозв'язок між Т і МC $[1,5]$.

Результати проведеного нами дослідження дозволили встановити, що низькі рівні ЗТ у хлопців із ГА пов'язані лише з окремими показниками ліпідного профілю - ЗХС та ХC ЛПНЩ за відсутності кореляцій між рівнями T та показниками вуглеводного обміну, що підтверджує дослідження А.O. Ogbera [21]. Що стосується $\mathrm{E}_{2}$, то його рівень, незалежно від віку та IMT, був прямо пов'язаний з ЗХС, що узгоджується 3 дослідженнями японських науковців [5].

Цікавим напрямком сучасних досліджень є обговорення ролі СЗГ у формуванні МС у чоловіків. Так, висловлюється припущення, що СЗГ є предиктором виникнення МС незалежно від рівня Т у чоловіків $[22,23]$. Водночас, Yeap B. et al. повідомляють, що в літніх чоловіків, незалежно від показників центрального ожиріння, саме низькі рівні Т (до нормального діапазону), але не СЗГ, пов'язані з IP [8].

Слід зазначити, що в проведених дослідженнях дорослі та літні чоловіки мали розгорнуту клінічну картину МС із наявністю ожиріння, гіпертонії, дисліпідемії та ІР. Водночас, як обстежені нами підлітки із ГА мали 
лише окремі ознаки метаболічних порушень проатерогенні зміни ліпідного профілю, частина хлопців - IP. Визначені зв'язки між статевими стероїдами та ліпідними порушеннями вимагають подальшого вивчення.

\section{Висновки}

Отже, отримані нами дані свідчать, що низькі рівні 3Т вже в підлітковому віці асоціюються 3 порушеннями ліпідного профілю, що може бути початком формування МС. Зазначене дозволяє розглядати ГА у хлопців, як один із значущих факторів виникнення МС у зрілому віці і потребує уваги клініцистів вже на момент первинного обстеження підлітків із затримкою статевого розвитку з подальшим динамічним спостереженням та патогенетичним лікуванням, спрямованим не тільки на покращення репродуктивного потенціалу юнаків, але й попередження формування та прогресування метаболічних порушень.

\section{Список використаної літератури}

1. Chrysohoou C, Panagiotakos D, Pitsavos C, et al. Low total testosterone levels are associated with the metabolic syndrome in elderly men: the role of body weight, lipids, insulin resistance, and inflammation; the Ikaria study. The review of diabetic studies. RDS. 2013;10(1):27-38.

2. Feingold KR, Brinton EA, Grunfeld C. The Effect of Endocrine Disorders on Lipids and Lipoproteins. [Updated 2020 Mar 9]. In: Feingold KR, Anawalt B, Boyce A, et al., editors. Endotext [Internet]. South Dartmouth (MA): MDText.com, Inc.; 2000. Available from: https://www.ncbi.nlm.nih.gov/books/ NBK409608

3. Laaksonen DE, Niskanen L, Punnonen K, et al. Sex hormones, inflammation and the metabolic syndrome: a population-based study. Eur J Endocrinol. 2003;149(6):601-608.

4. Лучицький $\mathrm{EB}$, Лучицький $\mathrm{B} €$. Сучасні погляди на віковий андрогенодефіцит у чоловіків. Ендокринологія. 2012;17(4): C. 56-60. (Luchytskyy YeV, V. Ye. Luchytskyy. Modern concept of age androgendeficiensy in males. Endocrinology. 2012;17(4): P. 56-60.).

5. Akishita M, Fukai S, Hashimoto M, et al. Association of low testosterone with metabolic syndrome and its components in middle-aged Japanese men. Hypertens Res. 2010;33(6):587-591.

6. Lapauw B, Goemaere S, Zmierczak H, et al. The decline of serum testosterone levels in community-dwelling men over 70 years of age: descriptive data and predictors of longitudinal changes. Eur J Endocrinol. 2008;159(4):459-468.

7. Harman SM, Metter EJ, Tobin JD, et al. Longitudinal effects of aging on serum total and free testosterone levels in healthy men. J Clin Endocrinol. 2001;86(2):724-731.

8. Yeap B, Chubb S, Hyde Z, et al. Lower serum testosterone is independently associated with insulin resistance in nondiabetic older men: the Health In Men Study. Eur J Endocrinol. 2009;161(4):591-598.

9. Kupelian V, Page ST, Araujo AB, et al. Low sex hormone-binding globulin, total testosterone, and symptomatic androgen deficiency are associated with development of the metabolic syndrome in nonobese men. J Clin Endocrinol. 2006;91(3):843-850.

10. Osuna JA, Gomez-Perez R, Arata-Bellabarba G, et al. Relationship between BMI, total testosterone, sex hormone-binding-globulin, leptin, insulin and insulin resistance in obese men. Archives of Andrology. 2006;52(5):355-361.

11. Kaufman JM, Vermeulen A. The decline of androgen levels in elderly men and its clinical and therapeutic implications. Endocrine Reviews. 2005;26(6):833-876.

12. Saely CH, Aczel S, Marte T, et al. The metabolic syndrome, insulin resistance, and cardiovascular risk in diabetic and nondiabetic patients. J Clin Endocrinol. 2005;90(10):5698-5703.

13. Протоколи надання медичної допомоги дітям за спеціальністю «Дитяча ендокринологія». К., 2006. - 94 c. (Protocols of medical care for children from the specialty «Pediatric Endocrinology». K., 2006. - 94 p.).

14. Marshall WA, Tanner JM. Variations in the pattern of pubertal changes in boys. Arch Dis Child. 1970;4:13.

15. Оцінка статевого розвитку хлопців (вікові нормативи): метод. рек. ДУ «ІОЗДП АМНУ»; Плехова ОІ [та ін.]. Х., 2010. 25 c. (Assessment of sexual development of boys (age standards): method. rivers SI «ICAHC NAMS»; Plehova OI [at al.]. Kharkiv, 2010. - 25 р.).

16. Турчина CI. Імуно-гормональні механізми та фактори ризику несприятливого перебігу дифузного нетоксичного зоба у пубертатному періоді. дис... д-ра мед. наук. Х., 2016. - 409 с. (Turchina S.I. Immuno-hormonal mechanisms and risk factors in regard of an unfavorable course of a diffuse nontoxic goiter at puberty. Dissertation for a Doctor of Medical Sciences. Kharkiv, 2016. - 409 p.).

17. Mathur RS, Moody LO, Landgrebbe S, et al. Plasma androgens and sex hormone binding globulin in the evaluation of hirsute patients. Fertil Steril. 1981:35(1):29-37.

18. Wickramatilake CM, Mohideen MR, Pathirana C. Association of metabolic syndrome with testosterone and inflammation in men. Ann Endocrinol (Paris). 2015;76(3):260-263.

19. Vikan T, Schirmer H, Njølstad I, et al. Low testosterone and sex hormone-binding globulin levels and high estradiol levels are independent predictors of type 2 diabetes in men. Eur J Endocrinol. 2010;162(4):747-754.

20. Arthur R, Rohrmann S, Møller H, et al. Prediabetes and serum sex steroid hormones among US men. Andrology. 2017;5(1):49-57.

21. Ogbera AO. Relationship between serum testosterone levels and features of the metabolic syndrome defining criteria in patients with type 2 diabetes mellitus. West Afr J Med. 2011;30(4):277-281

22. Haring R, Völzke H, Spielhagen C, et al. The role of sex hormonebinding globulin in the risk of incident metabolic syndrome: further evidence from a longitudinal population-based sample of adult men. Endocrine Abstracts. 2012;29:516.

23. Tint A, Hoermann R, Wong $\mathrm{H}$, et al. Association of sex hormonebinding globulin and free testosterone with mortality in men with type 2 diabetes mellitus. Eur J Endocrinol. 2016;174(1):59-68.

(Надійшла до редакиії 23.11.2020 р.)

\section{Влияние гипоандрогенемии на составляющие метаболического синдрома у подростков С задержкой полового развития}

\author{
Н.В. Шляхова ${ }^{1,2}$, С.И. Турчина ${ }^{1,2,3}$, А.В. Косовцова ${ }^{1,2}$ \\ 'ГУ «Институт охраны здоровья детей и подростков НАМН Украины», \\ г. Харьков \\ ${ }^{2}$ Харьковский национальный университет им. В.Н. Каразина, \\ $\mathrm{MOH}$ Украины \\ ${ }^{3}$ Харьковская медицинская академия последипломного образования, \\ МЗ Украины
}

Резюме. Цель - исследовать влияние гипоандрогенемии (ГА) на формирование компонентов метаболического синдрома (МС) у мальчиков с задержкой полового развития. Материал и методы. Комплексное исследование проведено у 55 подростков 14-18 лет с клиническими признаками задержки полового раз- 
вития и лабораторно подтвержденным сниженным уровнем тестостерона (<12,0 нмоль/л) (основная группа). Группу сравнения составили 44 практически здоровых сверстника с нормальным уровнем полового созревания. Оценивали половое и физическое развитие мальчиков. Определяли уровни общего тестостерона (ОТ) и эстрадиола ( $\left.\mathrm{E}_{2}\right)$, сексстероидсвязывающего глобулина (ССГ), общего холестерина (ОХС), триглицеридов (ТГ), холестерина липопротеидов высокой плотности (ХС ЛПВП), уровень глюкозы натощак и иммунореактивного инсулина в сыворотке крови. Рассчитывали соотношение (T/ $\left.\mathrm{E}_{2}\right)$, индекс свободного андрогена (ИСА) показатели холестерина липопротеидов низкой плотности (ХС ЛПНП) и коэффициента атерогенности (КА), индекс инсулинорезистентности НОМА. Статистический анализ выполнен в программе SPSS17.00. Результаты. У подростков с ГА снижение уровня ОТ сочеталось с достоверным уменьшением соотношения T/E ${ }_{2}(40,35 \pm 28,02$ y.e., $p<0,05)$ и ИСА $(22,08 \pm 6,05$ y.e., $p<0,05)$ на фоне снижения уровня ССГ $(28,11 \pm 3,64$ нмоль/л, р<0,05). При индивидуальном анализе у 23,6\% больных с ГА диагностированы признаки инсулинорезистентности. Установлено, что мальчики с ГА имели

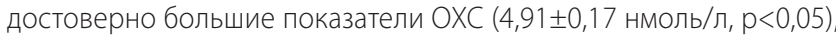
ТГ $(1,15 \pm 0,12$ нмоль/л, $р<0,05)$ и ХС ЛПНП $(2,65 \pm 0,19$ нмоль/л, $\mathrm{p}<0,05)$ по сравнению со здоровыми сверстниками. Доказано наличие отрицательных связей уровней ОТ, ССГ с содержанием ОХС и положительной связи $\mathrm{E}_{2}$ с ОХС, которые не зависели от возраста и индекса массы тела (ИМТ). Выводы. Низкие уровни ОТ у мальчиков уже в подростковом возрасте ассоциируются с нарушениями липидного профиля, которые могут быть предиктором формирования МС. Подростки с ГА требуют динамического наблюдения и комплексного лечения, направленного на улучшение репродуктивного потенциала и предупреждения прогрессирования метаболических нарушений.

Ключевые слова: мальчики, гипоандрогенемия, метаболический синдром.

\section{Influence of hypoandrogenemia on the components of metabolic syndrome in adolescents with a delayed sexual development}

\author{
N.V. Shlyakhova ${ }^{1,2}$, S.I. Turchina ${ }^{1,2,3}$, G.V. Kosovtsova ${ }^{1,2}$ \\ ${ }^{1} \mathrm{SI}$ «Institute for Children and Adolescents Health Care of the National \\ Academy of Medical Sciences of Ukraine», Kharkiv \\ ${ }^{2}$ V.N. Karazin Kharkiv National University \\ ${ }^{3}$ Kharkiv Medical Academy of Postgraduate Education, Ministry of Health of \\ Ukraine
}

Abstract. Purpose - to study the effect of hypoandrogenemia (HA) on the formation of metabolic syndrome (MS) components in boys with delayed puberty. Material and methods. A comprehensive study was carried out in 55 adolescents aged 14-18 years with clinical signs of delayed puberty and laboratory-confirmed decreased testosterone levels (<12.0 nmol/l) (main group). The comparison group consisted of 44 practically healthy peers with a normal level of puberty. The sexual and physical development of boys was assessed. The levels of total testosterone (TT) and estradiol $\left(E_{2}\right)$, sex hormone-binding globulin (SHBG), total cholesterol (TC) triglycerides (TG), high-density lipoprotein cholesterol (HDL-C), fasting glucose and immunoreactive insulin in serum were determined. The ratio $\left(T / E_{2}\right)$, free androgen index (FAI), low-density lipoprotein cholesterol (LDL-C) and atherogenic coefficient (AC), and insulin resistance index (HOMA-IR) were calculated. Statistical analysis was performed using SPSS17.00 software. Results. In adolescents with $\mathrm{HA}$, a decrease in TT level was combined with a significant decrease in the $T / E_{2}$ ratio $(40.35 \pm 28.02$ c.u., $p<0.05)$ and FAl $(22.08 \pm 6.05$ c.u., $p<0.05$ ) against the background of a decrease in the level of SHBG $(28.11 \pm 3.64 \mathrm{nmol} / \mathrm{l}, \mathrm{p}<0.05)$. Individual analysis showed signs of insulin resistance in $23.6 \%$ of patients with $\mathrm{HA}$. It was found that boys with HA had significantly higher levels of TC $(4.91 \pm 0.17 \mathrm{nmol} / \mathrm{l}$ $\mathrm{p}<0.05), \mathrm{TG}(1.15 \pm 0.12 \mathrm{nmol} / \mathrm{l}, \mathrm{p}<0.05)$ and LDL-C $(2.65 \pm 0.19 \mathrm{nmol} / \mathrm{l}$ $\mathrm{p}<0.05)$ compared with healthy peers. The presence of negative relationships between the levels of TT, SHBG with the content of TC and a positive relationship of $E_{2}$ with $T C$, which did not depend on age and body mass index (BMI), was proved. Conclusions. Low TT levels in boys already in adolescence are associated with abnormalities in the lipid profile, which may be a predictor of MS formation. Adolescents with HA require dynamic observation and complex treatment aimed at improving the reproductive potential and preventing the progression of metabolic disorders.

Keywords: boys, hypoandrogenemia, metabolic syndrome.

Для цитування: Шляхова НB, Турчина Cl, Косовцова ГВ. Вплив гіпоандрогенемії на складові метаболічного синдрому в підлітків із затримкою статевого розвитку. Ендокринологія. 2021;25(4):310315. DOl: 10.31793/1680-1466.2021.25-4.310.

Відомості про авторів: Наталія Василівна Шляхова, канд. мед. наук, старш. наук. співроб., ORCID: 0000-0003-2126-2184; Світлана Ігорівна Турчина, д-р мед. наук, старш. наук. співроб., ORCID: 0000-0002-0744-1242; Ганна Василівна Косовцова, канд. мед. наук ORCID: 0000-0002-7737-1518.

Особистий внесок: Н.В. Шляхова - набор та обчислювання матеріалу, написання тексту, С.І. Турчина - дизайн дослідження, написання та редагування тексту; Г.В. Косовцова — набор матеріалу

Фінансування: за бюджетні кошти в межах виконання НДР «Удосконалити систему медичного супроводу хлопців із затримкою статевого розвитку (ЗСР) з урахуванням ступеня гіпоандрогенії та коморбідних захворювань» (№ держреєстрації $0113 \cup 001068)$.

Декларація з етики: автори задекларували відсутність конфлікту інтересів і фінансових зобов'язань. 